\title{
Waging Protracted Naval War: The Strategic Leadership of Secretary of the U.S. Navy William Jones in the War of 1812
}

\section{Kevin D. McCranie}

William Jones a servi de secrétaire de la marine des États-Unis à partir de janvier 1813 jusqu'en décembre 1814. Bien qu'il n'ait pas été secrétaire pendant les premiers mois déterminants de la guerre de 1812, quand des frégates américaines ont à trois reprises défait leurs contreparties britanniques, Jones a employé une politique basée sur ces victoires américaines comme fondement pour développer une nouvelle stratégie soulignant prolongement et rupture à la place d'engagement avec l'objet de soumettre à la Grande-Bretagne des frais élevés. La conception, l'exécution, et les effets de cette stratégie de Jones aussi bien que ses résultats à long terme donnent une vue sur les difficultés et les opportunités que la marine des États-Unis a rencontrées pendant la guerre de 1812 .

During the first six months of the War of 1812, the 38-gun British frigates Guerriere, Macedonian, and Java struck their colors to frigates of the United States Navy. For the remainder of the war, the Americans failed to duplicate such results. ${ }^{1}$ A partial explanation stems from the Royal Navy's ability to adapt. As the world's largest navy the British service had significant flexibility that allowed the Admiralty to dispatch reinforcements to the North American station. The one ship of the line and five frigates present in June 1812 became, by the middle of the next year, ten ships of the line and sixteen frigates as well as one modified ship of the line known as a razee. By late 1814, the strength on the station had increased to twelve ships of the line, two razees, and

1 The largest ship captured by the Americans after 1 January 1813 was the Cyane, rated for 22 guns but mounting 32. It was normal for warships of the period to mount more guns than their rate would indicate and was also true with the 38-gun frigates captured during the war's first six months. Carrying more guns resulted from the evolution of ship armaments encompassing such disparate trends as mounting guns on previously unarmed areas of warships to the proliferation of the lighter-weight carronades. Details for the Cyane, Guerriere, Macedonian, and Java, National Archives, Kew, United Kingdom [hereafter NA], Admiralty Papers [hereafter ADM] ADM 7/556; Brian Lavery, Nelson's Navy: The Ships, Men and Organization, 1793-1815 (Reprint, Annapolis, MD, 1997), 40, 81-83; William James, Naval Occurrences of the War of 1812 (Reprint, London, 2004), 11-12.

The Northern Mariner/le marin du nord, XXI No. 2, (April 2011), 143-157 
twenty-nine frigates. ${ }^{2}$ Additional roving squadrons patrolled critical sea lines of communication. Convoys received stronger escorts and, in July 1813, the Admiralty directed its frigate captains to avoid single combat with the largest American frigates such as the Constitution. ${ }^{3}$ Though British material strength as well as choices about deployments and rules of engagement minimized Royal Navy losses, the Admiralty faced new challenges. The appointment of William Jones as secretary of the United States Navy in January 1813 led to the development of a new oceanic naval strategy that gave attacks on British commerce priority over battle with the Royal Navy in an effort to preserve America's warships while incurring costs on the British navy and protracting the war. ${ }^{4}$ The design, execution, and effects of Jones's strategy as well as its long-term results, deserve critique and illustrate both the difficulties and opportunities faced by the United States Navy while at war with the largest navy in the world.

Strategic direction for the United States Navy emanated from the office of the secretary of the Navy. Benjamin Stoddert, appointed to this position in 1798, set the precedent of powerful leadership. One author has asserted, "Power rested entirely with the Secretary, not only in the technical field of naval construction and equipment but also in the strategic and tactical control of naval operations." ${ }^{5}$ At the outbreak of the War of 1812, Paul Hamilton served as secretary of the Navy. With no appreciable background in maritime affairs, his appointment appears to have been more for political reasons than for relevant knowledge. ${ }^{6}$ In fact, one member of the House of Representatives declared that Hamilton "is about as fit for his place, as the Indian prophet would be for the Emperor of Europe." Though perhaps this assessment was unfairly harsh, Hamilton did not exercise effective operational control over the United States Navy. His orders were often vague, and he allowed his naval officers significant latitude in making decisions. Moreover, he

2 Ships in Sea Pay, 1 July 1812, 1813, NA, ADM 8/100; Admiralty Board Minutes, late 1814, $\mathrm{NA}, \mathrm{ADM} 7 / 266$. To make these calculations, frigates are warships rated from 32 to 44guns; ships of the line were 64-gun ships and larger; and razees were ships of the line with part of their armaments removed. They mounted 57 or 58 guns and were a response to America's large frigates such as the Constitution.

3 Croker to Warren, 10 February 1813, NA, ADM 2/1376/73-87; Croker to the Several Commanders in Chief ..., 10 July 1813, NA, ADM 2/1377/154-56.

4 This article is an adaptation of a paper presented at the 2008 Society of Military History Conference in Ogden, Utah. More recently, Stephen Budiansky, who recognized the earlier work of this author, has explored aspects of Secretary Jones's role in the War of 1812 on the high seas. See, "Giant Killer," Military History Quarterly (Spring 2009), 50-60.

5 Howard I. Chapelle, The History of The American Sailing Navy: The Ships and Their Development (Reprint of Edition from New York, 1949), 177. A contradictory interpretation has been posited by Edward $\mathrm{K}$. Eckert who asserted, "One thing is certain; no case can be made for Jones' [as Secretary of the Navy] directing the nation's naval strategy." See Navy Department in the War of 1812 (Gainesville, FL, 1973), 74.

6 Eckert, The Navy Department, 13; John K. Mahon, The War of 1812 (Gainesville, FL, 1972), 5 .

7 Macon to Nicholson, 25 March 1812, Library of Congress, Washington D.C. [hereafter LC], Joseph Nicholson Papers, vol. 5. 
placed an emphasis on squadron versus single ship operations and engaging British warships was encouraged for "the precious effects which victory will procure." 8 In late 1812, Hamilton was accused of incompetence and rumors surfaced that he took comfort in the bottle. Before the year's end, he had resigned. ${ }^{9}$

President James Madison selected William Jones as Hamilton's successor. Jones was justified in his claim that "My pursuits and studies have been intimately connected with the objects of the department."10 He had taken up arms against Britain during the American Revolution. Afterwards, he commanded merchant ships, became a businessman, and served a term in Congress. In 1801, President Thomas Jefferson offered to appoint him secretary of the Navy, but Jones declined. ${ }^{11}$ This led one of his friends in early 1813 to comment, "I could scarcely believe that you would have been drawn into Public life knowing how little ambitions [sic] you are in that pursuit." ${ }^{12}$ When accepting Madison's offer in January 1813, Jones wrote to the President "that your own and the public confidence far transcends my merit, ... but the sacred cause in which we are engaged and my confidence indeed attachment to the administration of our Government demands the Sacrifice of every personal consideration." 13 However, Jones continued, "the moment peace returns, ... I shall return to private life and to business." 14

As secretary of the Navy, Jones held numerous responsibilities, only one of which was direction of the oceanic naval war. President Madison, his cabinet, and various members and committees in Congress certainly provided guidance about what they wished to accomplish, but it was Jones who gave those ideas operational form. Moreover, extant correspondence between Jones and Madison was dominated by the situation on the Great Lakes and Lake Champlain, bordering the United States and British Canada. ${ }^{15}$ These waters - virtual inland seas isolated by the rapids on the St. Lawrence River from access by ocean vessels - were the scene of urgent efforts to build up naval forces by both sides. Although Madison made his wishes known about the war on the high seas, the secretary schooled the president about what might be accomplished by oceanic operations and how it could be accomplished. Jones, for example, explained

8 Hamilton to Rodgers, 22 June 1812, National Archives and Records Administration [hereafter NARA], RG45, Letters from Captains to the Secretary of the Navy, no. 125 [hereafter no. 125], reel 23/58.

9 Christopher McKee, A Gentlemanly and Honorable Profession: The Creation of the U.S. Naval Officer Corps, 1794-1815 (Annapolis, MD, 1991), 10-11.

10 Jones to Eleanor Jones (his wife), 23 January 1813, The Naval War of 1812: A Documentary History, eds. William S. Dudley et al. (Washington, DC, 1992), 2:34-35.

11 Jefferson to Jones, 16 March 1801, Jones to Jefferson, 20 March 1801, LC, Thomas Jefferson Papers, series 1; Mahon, War of 1812, 103-104. The most complete description of William Jones while secretary of the Navy can be found in Eckert, Navy Department.

12 Bainbridge to Jones, 1 March 1813, Historical Society of Pennsylvania, Philadelphia [hereafter HSP], U.C. Smith Collection, Papers of William Jones.

13 Jones to Madison, 14 January 1813, LC, The James Madison Papers [hereafter JMP], series 1 , reel 14.

14 Jones to William Young, 11 April 1813, HSP, Papers of William Jones.

15 Jones to Madison, Madison to Jones, various dates, LC, JMP, series 1, reels 15-16. 
"The difference between the Lake and the sea service is that in the former we are compelled to fight them at least man to man and gun to gun while on the ocean five British frigates cannot counteract the depredations of one Sloop of War." ${ }^{16}$

Such thoughts led Jones to develop a new concept of oceanic operations that he dispatched to five principal naval officers on 22 February 1813. He predicted that British naval strength on the North American station would increase during 1813, making it too risky for American warships to operate near the United States coast: "Our great inferiority in naval strength, does not permit us to meet them on this ground without hazarding the precious Germ of our national glory." Such a statement served as a warning to American naval officers that battles with the British navy would be discouraged since the dozen operational warships of the United States Navy did not possess the means to defeat a significant portion of the approximately 500 operational warships of Britain's Royal Navy. Moreover, Jones did not wish to hazard the moral advantage obtained from America's 1812 naval victories over the British frigates Guerriere, Macedonian, and Java, as well as the sloops Frolic and Alert. Rather than fighting British warships, Jones decided to target maritime commerce.

If any thing can draw the attention of the enemy, from the annoyance of our coast for the protection of his own, rich \& exposed Commercial fleets, it will be a course of this nature, $\&$ if this effect can be produced, the two fold object, of increasing the pressure upon the enemy \& relieving ourselves, will be attained. ${ }^{17}$

By defining maritime commerce as Britain's critical vulnerability, Jones planned to use British commerce as bait, forcing the Royal Navy to react in both costly and disruptive ways. Jones hoped to multiply these effects if the British designed their 1813 operations to counter the squadron-sized cruises that dominated American operations during the first half-year of the war. Jones stressed single-ship cruises targeting British commerce while avoiding battle with the Royal Navy. This way, the secretary hoped to husband the strength of the United States Navy. At the same time, he defined success as forcing the British navy to sustain costly deployments off the United States coast, throughout the North Atlantic, and eventually beyond.

Jones could not have hoped for a more compliant adversary. During the same month he took over as head of the Department of the Navy of the United States, the first lord of the British Admiralty declared: "It is evident that the Enemy's frigates do not wish

16 Jones to Madison, 26 October 1814, LC, JMP, series 1, reel 16.

17 Circular Letter, Jones to Rodgers, Decatur, Bainbridge, Stewart, Morris, 22 February 1813, NARA, RG45, Letters from the Secretary of the Navy to Naval Officers, no. 149 [hereafter no. 149], reel 10/266, 77. For the strengths of the two navies, see Ships in Sea Pay, 1 Jan 1813, NA, ADM 8/100; Ships of the United States Navy, winter 1811, The New American State Papers: Naval Affairs, ed. K. Jack Bauer (Wilmington DE, 1981), 1:71. The 1811 figure for the United States Navy remains valid for early 1813 since the Americans failed to commission any ocean-going warships between late 1811 and early 1813 . By removing losses sustained in the war's first months including the Wasp, Nautilus, Vixen, and Viper, the remainder provides a snapshot of the navy. 
to proceed to Sea singly, \& we must be prepared accordingly." 18 The British were anticipating squadron-sized American operations similar to those conducted during 1812 and these had to be countered more effectively than in the past. In the words of an Admiralty assessment of December 1812, "The War has now continued some months without any advantage on our parts." The British government demanded from Admiral Sir John Borlase Warren, the commander in chief employed on the American and West Indian Station, "more active measures and of more successful exertions" against the United States Navy. Though the Admiralty was "aware of the great uncertainty of all Naval Operations and of the difficulty of preventing the occasional excursions of an enterprizing Enemy," the Admiralty expected in the aftermath of America's 1812 naval victories that Warren would restore "the honor of His Majesty's Arms and the preeminence of the Naval Power of the Country." ${ }^{19}$

British naval leaders in London thus saw a need to engage warships of the American navy while Jones wished to avoid battles and target maritime trade. However, the newly appointed secretary of the Navy needed his senior leadership to buy into his new strategy. Jones ended the 22 February letter to his principal officers with the following invitation: "Your own ideas of a cruise with this general view will be acceptable to me." This was the beginning of an extensive correspondence with the navy's uniformed leadership. Jones endeavored to work the ideas from senior officers into plans that would support his strategy. For example, Commodore John Rodgers proposed a cruise by his heavy frigate President to the Azores and Madeira since this area served as a rendezvous for scattered British East and West India convoys. ${ }^{20}$ The President would then sail north and target commercial shipping around Britain and Ireland before provisioning at a port in Denmark. Subsequently Rodgers suggested a much further ranging cruise, to the East Indies. Jones determined that the first part of the plan would fit his strategy, but judged that a cruise into the Indian Ocean was too risky and refused to allow Rodgers to sail past the Cape of Good Hope or at the furthest Mauritius. ${ }^{21}$

Commodore Stephen Decatur of the heavy frigate United States suggested sweeping up a small British squadron reportedly off the South Carolina coast, and then cruising in the track of British merchant vessels returning to England from the East and West Indies. ${ }^{22}$ Jones, however, had intelligence that the Royal Navy squadron off South Carolina had dispersed; instead, he suggested that Decatur operate against British commerce in the West Indies. In contrast to this diplomatic response to a senior officer, Jones had no qualms ordering the recently promoted Captain Jacob Jones of the frigate Macedonian to also operate in the West Indies and "compare your ideas [with Decatur] so

18 Melville to Warren, 9 January 1813, National Maritime Museum, Greenwich, United Kingdom [hereafter NMM], Warren Papers, WAR/82/41-45.

19 Croker to Warren, 2 December 1812, NA, ADM 2/1107/346-51.

20 Henry Veitch (Consul Madeira) to Croker, 2 October 1813, NA, ADM 1/3845.

21 Rodgers to Jones, 22 April 1813, NARA, No. 125, Reel 28/28; Jones to Rodgers, 29 April 1813, NARA, RG45, Confidential Letters of the Secretary of the Navy [hereafter CL] 14. 
as to cruise separately $\&$ spread over as great a space as possible." ${ }^{23}$ In another instance, Captain John Smith of the frigate Congress received seven possible cruising options from Jones who then explained, "On the eve of Your departure inform me of the route you contemplate." ${ }^{24}$ Smith chose a station along the equator to intercept the East India and South America commerce. ${ }^{25}$ As officers "chose" their cruising grounds, Jones provided more specific orders to his remaining commanders to avoid leaving important regions uncovered. Jones ordered the brig Argus to operate around the British Isles, and the commander of the frigate Chesapeake received instructions to intercept commerce destined for Canada. ${ }^{26}$

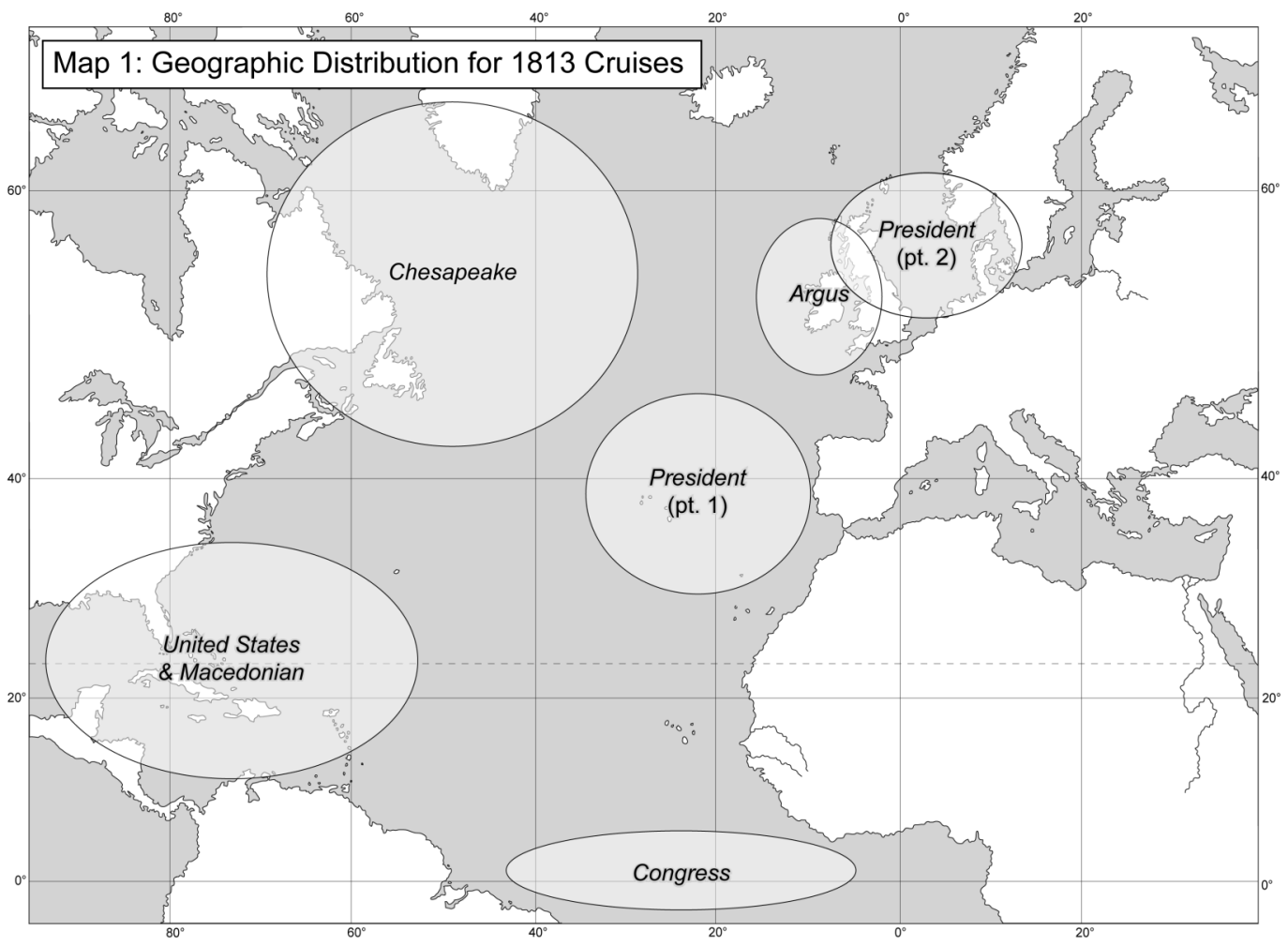

Orders to American naval officers emphasized single ship cruises that, although sacrificing concentration of force, would yield good results by compelling the British to disperse their warships still more widely. As Jones explained, "I have never doubted the effect upon the enemy, would be in proportion to the space covered on the ocean by our cruisers, in those tracks most frequented by his immensely rich, \& wide spread

23 Jones to Decatur, 15, 17 March 1813, Jones to Jacob Jones, 17 Mar 1813, NARA, no. 149, reel 10/304-309.

24 Jones to Smith, 21 March 1813, NARA, no. 149, reel 10/314-16.

25 Letter from an officer of the Congress, 12 December 1813, printed in Repertory (Boston), 16 December 1813. Jones to Evans, 6 May 1813, Jones to Allen, 5 June 1813, NARA, CL 19-22, 29-31. 
commerce. ${ }^{27}$ Cruises by U.S. warships into areas the British considered safe from attack might be particularly useful in spurring the enemy to costly overreactions. Commerce raiding by single ships thus promised to increase Britain's wartime expenditures and disrupt other operations, including possible withdrawals of ships from the United States coast. Jones ordered the commander of the Argus to destroy trade around the British Isles since, "This would carry the war home to their direct feelings and interests, and produce an astonishing sensation. ${ }^{28}$ For similar reasons he supported operations deep in Canadian waters by the frigate Chesapeake: "The enemy will not, in all probability, anticipate our taking this ground [Gulf of St. Lawrence] with our Public Ships of war." ${ }^{, 29}$

Targeting merchant vessels in nearly every corner of the Atlantic had the potential to stretch British naval deployments, but the Royal Navy's strength of more than 500 warships gave it a considerable degree of elasticity in the face of unanticipated threats. Jones needed additional methods to "in some degree compensate for the great inequality compared with that of the Enemy." ${ }^{30}$ One answer was to destroy captured vessels. For financial reasons, naval captains preferred to send captures into friendly ports so that they could be sold as prizes of war, and thereby entitle the officers and men of the warship to part or all of the proceeds. ${ }^{31}$ Jones's orders explained the drawbacks of this conventional approach: "A Single Cruiser, if ever so successful, can man but a few prizes, and every prize is a serious diminution of her force." By contrast, "a Single Cruiser, destroying every captured Vessel, has ... the power perhaps, of twenty acting upon pecuniary views alone." 32 "As there is no way of annoying our enemy so effectually as through his Commerce," Jones wrote to one frigate captain, "let devastation be the standing order of your cruize." ${ }^{33}$

The hard fact that the British fleet outnumbered the United States Navy by a margin of nearly 50 to 1 in 1813 made Jones's strategy a risky one, but it was a calculated risk. In the face of such daunting odds an obvious alternative was to keep the United States warships in port, and at least tie down the British squadrons that would be needed to guard against a breakout. Yet Jones immediately dismissed such a "fleet in being" strategy: "nothing could more effectually promote his [British] views, than an opportunity of blockading in port our naval force, which one tenth part of the force necessary to watch their motions on the ocean would accomplish." ${ }^{34}$ American warships in port, moreover, would be vulnerable to British amphibious operations, as would indeed be demonstrated later in the war. A British operation in Maine involving ground and naval forces during the summer of 1814 resulted in the burning of the Adams, a flushdecked corvette mounting 27 guns, and the British raid on Washington witnessed the

\footnotetext{
27 Jones to Smith, 21 March 1813, NARA, no. 149, reel 10/314-16.

28 Jones to Allen, 5 June 1813, NARA, CL 29-31.

29 Jones to Evans, 6 May 1813, NARA, CL 19-22.

30 Jones to Parker, 8 December 1813, Naval War of 1812, eds. Dudley et al., 2:294-96.

31 McKee, Gentlemanly and Honorable, 341.

32 Jones to Parker, 8 December 1813, Naval War of 1812, eds. Dudley et al., 2:294-96.

33 Jones to Jacob Jones, 3 May 1813, NARA, CL 16-17.

34 Jones to Smith, 21 March 1813, NARA, no. 149, reel 10/314-16.
} 
destruction of an American frigate and a ship-sloop. Though the odds against America's warships at sea appeared long, the odds in port were arguably worse.

As it was, Jones's single-ship raiding policy soon bore fruits. One example was the cruises by the President and Congress during the summer of 1813. Though the two warships sailed in company from Boston, they soon split up with the President operating as far north as the Arctic and the Congress patrolling along the Equator. The departure of the two frigates from Boston confirmed the British assessment that the United States Navy would conduct squadron-sized operations, and they reacted accordingly, dispatching forces in pursuit that were larger and costlier than necessary to guard against single-ship commerce raids. Even when it became obvious that the two American warships operated singly, the British still had to find them, and the search for the Americans disrupted operations from the Equator to the Arctic. ${ }^{35}$ Of Commodore John Rodgers who commanded the President, a British newspaper mused sardonically about "how flattering it must be to him to learn, that not single ships but squadrons were dispatched after him, and one specifically under the command of an Admiral. ${ }^{36}$ Rodgers had every right to assert that he had caused disruptions to the Royal Navy equivalent to "more than a dozen times the force of a single Frigate." ${ }^{37}$

Broader policy imperatives also drove Jones to accept the risk of oceanic operations so as to obtain moral victories against the stronger power. Overall, the first year of the War of 1812 did not go as planned for the United States, but operations at sea had resulted in several tactical victories and helped sustain flagging popular support for the conflict. In October 1814, Jones noted that "an increase in force on the Ocean is strongly urged by public writers and by the Legislature." 38 The capture of the British sloop Epervier in early 1814 was precisely the sort of achievement the country needed and led Jones to recount: "I like these little events they keep alive the national feeling and produce an effect infinitely beyond their intrinsic importance." 39

Even so, Jones endeavored to limit the risks to his warships. Writing to one commander in January 1814, he stressed the need to avoid "all unnecessary contact with the Cruisers of the enemy, even with an equal, unless under circumstances that may ensure your triumph without defeating the main object of your Cruise, or jeopardize the safety of the vessel under your Command." ${ }^{40}$ Much as a victory over an enemy warship might boost morale, he realized that even a successful engagement would almost certainly require the American warship to come into port for repairs. That eventuality

35 Rodgers to Jones, 27 September 1813, NARA, No. 125, Reel 31/100; Log Congress, MayDecember 1813, RG24; The Admiralty to Charles Paget, 10 July 1813, NA, ADM 2/1377/145-49; John Spratt Rainer to Young, 28 August 1813, NA, ADM 1/573/375A; Warren to Croker, 16 October 1813, NA, ADM 1/504/223; Dixon to Croker, 20 August 1813, NA, ADM 1/21/83.

36 The Morning Chronicle (London), 13 November 1813.

37 Rodgers to Jones, 27 September 1813, NARA, No. 125, Reel 31/100.

38 Jones to Madison, 26 October 1814, LC, JMP, Series 1, Reel 16.

39 Jones to Madison, 10 May 1814, LC, JMP, Series 1, Reel 16.

40 Jones to Joseph Bainbridge, 16 January 1814, NARA, CL 91-93. 
would significantly diminish the small fleet's presence at sea and thus undercut the larger strategic goals of forcing the British to disperse their effort in the face of widespread commerce raiding operations. Duels between warships, moreover, were inherently extremely risky; the British could win. Jones cited "The success of the Argus [which]... in the course of but a few days [of operations against merchant ships in the narrow waters between England and Ireland], was astonishingly great; and had the gallant spirit of Captain [William H.] Allen, but submitted to the restraint of his excellent judgment, he would have rendered more essential service to his country, perhaps, than any single vessel ever did." ${ }^{41}$ Instead, Allen chanced an engagement with a British brig and lost. In the aftermath of the Chesapeake's capture on 1 June 1813, Jones provided his clearest summation about the risks of combat versus the annoyance of the British.

Whilst the gallant spirit and high minded character of our Naval Officers justly excites the national admiration, their zealous devotion to the cause and honour of their country must be tempered by judgment and sound policy. The glory we have acquired is too precious to commit to the wiles of an insidious foe. The just and honorable contest in which were are engaged must be directed to the most effectual annoyance of the enemy, not to Naval Chivalry in which the numbers and force of the respective combatants are unequal by example. ${ }^{42}$

Yet, in the end, Jones knew some warships would not return. Describing the capture in early 1814 of the Frolic, a ship-sloop mounting 22 guns, he wrote that "the loss ... which though much to be regretted is among the casualties of War..."43

Such losses could not readily be made good. There had been no naval vessels under construction at the outbreak of hostilities ${ }^{44}$ (see Table 1 next page) and many of the additional vessels built under wartime programs only became operational after the conclusion of hostilities. To mitigate attrition, Jones slowed the operational tempo. During the first six months of the war (before Jones's appointment), eleven frigates sailed on extended cruises, but during the remainder of the war, American frigates embarked on only ten cruises.

Currying of resources in the face of the Royal Navy's dominance and the absence of reinforcements for the U.S. fleet only postponed the near inevitable capture or destruction of American warships as a result of chance encounters with superior enemy forces, blockades of U.S. ports, and amphibious raids into those ports. While the British failed to capture an American frigate during 1812, increases in British strength and the Royal Navy's successful responses to United States initiatives made oceanic operations by the United States Navy increasingly risky as the war progressed. After 1812, the British turned back or captured half the United States frigates that proceeded to sea. ${ }^{45}$

41 Jones to Warrington, 26 February 1814, NARA, CL 102-105.

42 Jones to the Editors of the National Intelligencer, 9 June 1813, NARA, no. 125, reel 29/12 1/2.

43 Jones to Joseph Bainbridge, 13 June 1814, NARA, no. 149, reel 11/340.

44 Peter J. Kastor, "Toward 'the Maritime War Only': The Question of Naval Mobilization, 1811-12," Journal of Military History LXI (July 1997), 472-73.

45 This does not include short cruises in 1812 when the Constitution sailed in July and the Essex in September. The long cruises of 1812 include the following: President, Congress, 


\begin{tabular}{|c|c|c|c|c|c|}
\hline $\begin{array}{c}\text { Ships } \\
\text { (Jan. 1813) }\end{array}$ & Rate & $\begin{array}{l}\text { Obtained } \\
\text { during war }\end{array}$ & Rate & $\begin{array}{c}\text { How } \\
\text { Obtained }\end{array}$ & $\begin{array}{c}\text { Fate } \\
\text { (as of } 1 \text { Dec. 1814) }\end{array}$ \\
\hline Constitution & 44 & & & & Ready at Boston \\
\hline United States & 44 & & & & Blockaded at New London \\
\hline President & 44 & & & & Ready at New York \\
\hline Chesapeake & 36 & & & & Captured (Jun. 1813) \\
\hline Congress & 36 & & & & Laid up at Portsmouth, NH \\
\hline Constellation & 36 & & & & Blockaded at Norfolk \\
\hline Essex & 32 & & & & Captured (Mar. 1814) \\
\hline Hornet & Sloop & & & & Ready at New York \\
\hline Argus & Brig & & & & Captured (Aug. 1813) \\
\hline Siren & Brig & & & & Captured (Jul. 1814) \\
\hline \multirow[t]{16}{*}{ Enterprize } & Brig & & & & Withdrawn from Service \\
\hline & & Adams & 26 & Refitting & Burned (Sep. 1814) \\
\hline & & Macedonian & 38 & Prize & Blockaded at New London \\
\hline & & Wasp & Sloop & Built & Lost at sea (Date unknown) \\
\hline & & Frolic & Sloop & Built & Captured (Mar. 1814) \\
\hline & & Peacock & Sloop & Built & Ready at New York \\
\hline & & Erie & Sloop & Built & Blockaded at Baltimore \\
\hline & & Ontario & Sloop & Built & Blockaded at Baltimore \\
\hline & & Argus & Sloop & Built & Burned at Washington \\
\hline & & Rattlesnake & Brig & Purchased & Captured (Jul. 1814) \\
\hline & & Java & 44 & Built & Fitting out at Baltimore \\
\hline & & Guerriere & 44 & Built & Fitting out at Philadelphia \\
\hline & & Columbia & 44 & Built & Burned at Washington \\
\hline & & Washington & 74 & Building & Fitting out at Portsmouth, NH \\
\hline & & Independence & 74 & Building & Fitting out at Boston \\
\hline & & Franklin & 74 & Building & Building at Philadelphia \\
\hline
\end{tabular}

Table 1: status of American vessels.

Overall, Jones's time as secretary of the Navy witnessed the loss of two frigates and five smaller ocean-going warships. In addition, the brig Enterprize returned to port without most of her cannons because her crew had heaved them overboard in a desperate bid to escape a pursing British frigate. Now disarmed, she was withdrawn from oceanic service for the remainder of the war. Moreover, by the end of 1814, five warships could not sail because of the British blockade and a sixth had been laid up and the crew sent for service on the lakes bordering the United States and British Canada. That left the

United States sailed June; Essex sailed in July; Constitution sailed in August; President, Congress, United States, Essex, and Constitution sailed in October; and the Chesapeake in December. The 1813-15 sailings are as follows: Constellation in February 1813 (prevented); the President and Congress in April 1813 (to sea); the United States and Macedonian in June 1813 (prevented); and the Chesapeake in June 1813 (captured); the President and Constitution in December 1813 (to sea); the Constitution in December 1814 (to sea); the President in January 1815 (captured). 
American ocean-going navy with only four operational warships. Additional vessels procured under wartime programs would not be available for some months to come.. ${ }^{46}$

Jones could not protract the war indefinitely. In the face of Britain's superiority by a factor of more than fifty to one in ocean-going warships the best he could achieve was to extend the ocean struggle for a finite period. Time was not on Jones's side as numbers began to tell, allowing the British navy to slowly whittle down the United States Navy.

Another problem for Jones was funding. Taxes only paid for a small percentage of the United States government's expenditures during the War of 1812. This forced the treasury to raise money through loans and by issuing treasury notes, and the results did not meet expectations ${ }^{47}$ In October 1814 Jones lamented: "With respect to money the Department is truly in the most untoward situation. ... I am destitute of money in all quarters. Seamen remain unpaid and the recruiting Service is at a stand. I have none for the most urgent contingent purposes."48 Oceanic operations were extremely costly. Without steady funding, Jones's ability to conduct these endeavors became even more limited as the war progressed, and particularly as 1814 drew to a close.

With this bleak picture, Jones decided to step down as secretary of the Navy. He had warned President Madison in late April 1814 when he offered to make the resignation immediate. His stated reason stemmed from the embarrassment resulting from personal debt incurred from a failed commercial venture prior to his appointment as secretary of the Navy. Given the state of the United States Navy, an alternate argument could be made that Jones felt the naval war had run its course. The financial weakness of the United States coupled with the attrition of the United States Navy and the potential for further losses because of British predominance led Jones to liken his position to "standing upon Gun Powder with a slow match near it." 49 Getting out in 1814 would keep his reputation intact. One thing is certain, Madison did not want Jones to resign, and the president wrote of "the gratification I have experienced in the entire fulfilment of my expectations, large as they were, from your talents \& exertions." Eventually, the president and his secretary of the Navy reached a compromise that Jones would serve until 1 December $1814 .^{50}$

In his last days as secretary Jones crafted a final set of cruising orders. These

46 Smith to Jones, 9 June 1814, NARA, no. 125, reel 37/42; Biddle to Jones, 19 November 1814, NARA, RG45, Letters from Commanders to the Secretary of the Navy, no. 147, reel 5/82; Renshaw to Jones, 18 July 1814, NARA, RG45, Letters from Officers below the Rank of Commander to the Secretary of the Navy, no. 148, reel 13/22; Jones to Madison, 26 October 1814, LC, JMP, series 1, reel 16; Jones, Report on the State of the Navy, 22 February 1814, New American State Papers, ed. Bauer, 4:198-201; Paul H. Silverstone, The Sailing Navy, 1775-1854 (Annapolis, MD, 2001), 23, 28, 30, 32, 34-36, 39, 46.

48 Jones to Madison, 15 October 1814, LC, JMP, series 1, reel 16.

49 Jones to His Wife, 6 November 1814, HSP, Papers of William Jones.

50 Madison to Jones, [26] April 1814, Jones to Madison, 25 April, 11 September 1814, LC, JMP, series 1 , reel 16 . 
were only partially implemented because of funding problems, the strength of British naval deployments, and the termination of the war. The overarching target remained British commerce with the object of incurring costs on Britain and its navy. The Constitution and Congress received traditional instructions to operate singly. ${ }^{51}$ Jones directed the new large frigate Guerriere to sail from the Delaware in company with a schooner that could carry extra supplies and serve as a scout. ${ }^{52}$ Plans also called for the President to sail from New York for Asia in company with the sloops of war Hornet and Peacock as well as store ships, and they were expected to operate for a much longer period than any previous cruise. ${ }^{53}$ The most innovative feature involved the sailing of small squadrons to the West Indies and the Mediterranean. Each would consist of five vessels resembling privateers. ${ }^{54}$ Such commerce raiders were generally procured, fitted, and manned by private citizens as a type of business venture seeking financial gain from the capture of commerce belonging to hostile states. For privateers to be financially successful, they needed to get their captures into friendly ports, but this proved ever more difficult given the strength and deployments of the British navy. Jones realized that the destruction of their prizes would allow the five-vessel privateer-like naval squadrons to continue their missions for a longer period and with greater effect than traditional privateers.

Jones's plans showed continued innovation, but at the same time, it was clear that his oceanic strategy had approached the limits of its effectiveness. The Congress was not fully manned. The Guerriere's departure from the Delaware would be difficult, perhaps impossible, to achieve because of a powerful British blockade squadron and favorable geography for exercising that blockade, while funding problems slowed the creation of the West Indies and Mediterranean privateer-like squadrons and neither sailed before the ratification of the peace treaty.

At sea, additional constraints added to American difficulties. There were only so many bodies of water. Every time United States warships plied a region, British responses made it more difficult for the Americans to obtain similar effects. This increasingly limited Jones's options and forced him to exploit new areas, but those regions that remained by late 1814 could only be reached by long and, often, dangerous passages. One could argue that Jones's strategy had run its course and the war came to an end at an opportune time.

It would be all too easy to label Jones's strategy a failure. American warships destroyed few vessels when compared to the immense size of the British merchant fleet. Privateers, over which Jones had little or no control, had a much greater quantifiable impact with one author estimating that American warships captured 165 merchant vessels

\footnotetext{
51 Jones to Stewart, 29 November 1814, Jones to Morris, 30 November 1814, NARA, CL 21720.

52 Jones to Rodgers, 30 November 1814, NARA, CL 218-19.

53 Jones to Decatur, 17, 29 November 1814, NARA, CL 210-12, 216-17.

54 Jones to Perry, Jones to Porter, 30 November 1814, NARA, CL 220-23.
} 
compared to 1,344 by American privateers. ${ }^{55}$ These numbers should be viewed as a ratio rather than being treated as exact; Faye Kert has argued that it is impossible to determine the exact number of British merchant vessels captured and destroyed by the Americans. ${ }^{56}$ Jones looked beyond the raw numbers of British merchant vessels captured and understood what historian Jan Glete has concluded: "even a small American fleet ... was able to enforce high protection costs on Britain." 57 In a letter to Commodore Rodgers concerning the latter's 1813 summer cruise, Jones explained, "The effects of your Cruize however is not the less felt by the enemy either in his Commercial or Military Marine, for while you have harassed and enhanced the dangers of the one, you provoked the pursuit $\&$ abstracted the attention of the other to an extent perhaps equal to the disproportion of our relative forces." 58 As long as the United States Navy survived and followed the strategy laid out by Jones, the Royal Navy had to react, expend precious resources, maintain or increase its deployments, and refine a convoy system that was costly to both merchants and the British navy.

The American strategy caused the British considerable irritation. In early 1813, the secretary of the British Admiralty asserted to Admiral Sir John Borlase Warren, the commander in chief employed on the America and West Indies station, that "their Lordships have, not without inconvenience to other Services, placed under your command a force much greater in proportion than the National Navy of the Enemy opposed to you would seem to warrant." ${ }^{59}$ The Admiralty continued to reinforce Warren's command with an object of destroying or minimizing the effectiveness of the United States Navy. ${ }^{60}$ The first lord of the Admiralty warned Warren in June 1813 that "any more naval disasters, more especially if they could fairly be ascribed to want of due precaution, would make a strong impression on the public mind in this Country." 61 Warren, for his part, lamented that single American warships at sea "are such small \& Difficult Objects to hit - that our chances are few indeed \& the good Fortune of these Rascally privateer Frigates makes me almost Despair of ever seeing them."62 The inability to destroy the United States Navy led to critiques of Warren's conduct. A letter to the editor in the influential British journal The Naval Chronicle argued that Warren "sailed from England with the confidence of the nation - that he will possess it on his return, I greatly doubt ... I fear they have shewn, that the British lion is sound asleep ... It is too certain that little has been done, certainly nothing great or worthy of this powerful fleet." The writer, however, believed the naval failures went beyond Warren to

55 The Naval War of 1812, ed. Robert Gardner (Great Britain, 1998; reprint 2001), 28.

56 Faye Kert, "The Fortunes of War: Commercial Warfare and Maritime Risk in the War of 1812," The Northern Mariner (October 1998), 2.

57 Jan Glete, Navies and Nations: Warships, Navies and State Building in Europe and America, 1500-1860 (Stockholm, 1993), 2:395.

58 Jones to Rodgers, 4 October 1813, Naval War of 1812, eds. Dudley et al., 2:254-55.

59 Croker to Warren, 10 February 1813, NA, ADM 2/1376/73-87.

60 Ships in Sea Pay," 1 July 1813, NA, ADM 8/100.

61 Melville to Warren, 4 June 1813, NMM, WAR/82/73-77.

62 Warren to Barrie, 19 January 1814, 1812, Naval War of 1812, eds. Dudley et al., 3:16-17. 
include "the apathy and supineness of the B[oard] of $\mathrm{A}$ [dmiralty]." In conclusion, he indicted the Admiralty as "novices."

Yet, the Admiralty had an unenviable task of balancing deployments. Until early 1814, Britain faced Napoleonic France. This war had continued with one short respite since 1793. The French navy was much larger than the American navy and included numerous ships of the line whereas the Americans had no operational line of battle ships before the termination of the War of 1812. Moreover, the geographic distinctiveness between the American and French theaters of operations added to the difficulty of the British Admiralty's task. The War of 1812 forced the Admiralty to alter its worldwide naval deployments. Forces in North American waters multiplied from twenty-three warships in mid-1812 to 120 in late 1814. The number of ships of the line increased from one to twelve along with two cut-down ships of the line called razees. Frigate strength increased from five to twenty-nine. The Leeward Islands, Jamaica, and South American stations continued to demand large squadrons including some of Britain's best warships. Small squadrons routinely patrolled the busy sea-lanes around the Azores, Madeira and the Canaries searching for American commerce raiders and protecting British convoys. Around the British Isles, the threat of American naval operations forced the Admiralty to maintain significant deployments even after the defeat of Napoleon. However, deployments shifted from the English Channel to the southern approaches to the English Channel, the coast of Ireland, and from Scotland to the north in order to better cover convoy arrivals. ${ }^{64}$ Convoys themselves received stronger escorts. In 1812, convoys from the West Indies to England routinely sailed under the escort of a single frigate. These single warships often became squadrons during the War of 1812. The escorts protecting West India convoys generally grew to include a line of battle ship, a frigate and at least two sloops. In May 1814, the secretary of the British Admiralty explained that "Each convoy therefore equaled in force the whole American navy; the consequence of which was, that not a single merchant-ship had been taken which sailed under convoy, and that no convoy had been at all disturbed, except by weather." ${ }^{\text {"5 }}$ British naval deployments minimized commercial losses, but concurrently, the Royal Navy had to maintain a large fleet including many ships of the line and large frigates even after the termination of hostilities with Napoleonic France in 1814. If the British could have destroyed the United States Navy or forced the United States to rely solely on privateers that were smaller in size than warships and less apt to fight when facing the Royal Navy, the British could likely have economized more at sea by decommissioning a greater number of ships of the line and frigates that were both manpower intensive and costly to operate. Instead, the possibility of facing the powerful frigates and sloops of the United States Navy continued to be an expensive commitment for Britain. This can be seen through the

63 Letter to the Editor, Albion, 16 December 1813, Naval Chronicle XXXI (January to June 1814), 118-20.

64 Ships in Sea Pay, 1 June 1812, NA, ADM 8/100; Admiralty Board Minutes, late 1814, NA, ADM 7/266.

65 Statement by Croker, 13 May 1814, House of Commons, Parliamentary Debates. ed. T.C. Hansard, 27:869; Croker to Laforey, 9 December 1812, NA, ADM 2/1107/369-71. 
operational strength of the British fleet. During 1812 and 1813, the Royal Navy deployed slightly more than five hundred warships. The fall of Napoleon in the spring of 1814 should have resulted in a major drawdown. Though operational strength did decline, Royal Navy deployments still totaled approximately 350 warships in late 1814 of which 33 were ships of the line and razees and 83 were frigates. To be sure, the British maintained squadrons in places that had little to do with the War of 1812 like the Mediterranean and the East Indies; however, operations relating to the war against the United States accounted for more than half Britain's warships in late $1814 .{ }^{66}$

Jones's strategy inflicted significant costs on the Royal Navy by creating a festering irritation that could not be eliminated before hostilities concluded. To sustain this irregular naval war, Jones explained, "The species of force called for is undoubtedly well calculated to annoy the enemy and in order to meet the wishes which have been expressed on the subject by the President and in accordance with my ardent desire to employ every possible means of annoyance against the enemy." ${ }^{67}$ In this passage, Jones used both "annoy" and "annoyance" to describe desired strategic effects. The British navy was too powerful to defeat; instead, Jones devised a strategy to protract the war and make it expensive for Britain. As long as the war at sea against the Americans festered, the British navy had to remain on a war footing and British merchants could not return to more efficient and less costly peacetime practices. This was greatly desired among the British political public since the War of 1812 took place at the end of more than two decades of war with Revolutionary and then Napoleonic France.

Beginning in January 1813, Jones crafted the United States Navy's oceanic strategy. Moreover, Jones was the operational planner who designed the cruising orders for navy, thus creating the tangible element of the strategy at sea. ${ }^{68}$ President Madison, the available evidence suggests, was involved in oceanic naval policy, but he left the strategy and conduct of operations in the hands of Jones who had the great advantage of understanding the intricacies and vulnerabilities of the global maritime commercial system. Jones was the driving force in protracting an oceanic naval war that provided dividends to the United States at a significant cost to the British navy. This was a considerable achievement in the face of overwhelming British predominance.

66 Ships in Sea Pay, 1 July 1812, 1813, NA, ADM 8/100; British Deployments, late 1814, NA, ADM 7/266.

67 Jones to Madison, 26 October 1814, LC, JMP, series 1, reel 16.

68 This was illustrated when news of the loss of the United States brig Rattlesnake appeared in the papers. Jones had to inform Madison of the general nature of her cruising order as if this was the first that the President had heard of it. See Jones to Madison, 30 July 1814, LC, JMP, series 1, reel 16 . 
